\title{
Larger Elm Leaf Beetle, Monocesta coryli (Say) (Insecta: Coleoptea: Chrysomelidae) ${ }^{1}$
}

Michael C. Thomas ${ }^{2}$

\section{Introduction}

The larger elm leaf beetle, Monocesta coryli (Say), is one of the most conspicuous members of Florida's leaf beetle fauna. Although usually uncommonly collected in this state, it occasionally is abundant enough to cause defoliation of both native and exotic elms (Ulmus spp.) in ornamental and natural settings.

\section{Distribution}

There are many Neotropical species of this genus, but only $M$. coryli is found in the United States. Wilcox (1965) listed it as occurring from Pennsylvania south to Florida and west to Kansas. However, $M$. coryli does not appear to be evenly distributed throughout its range. Clark (1986) reported $M$. coryli as new to Ohio and hypothesized that it had recently spread to that state. In Florida, it occurs from the Panhandle south to the middle of the peninsula. Blatchley (1924) first reported it from Florida from the town of Palmetto, Manatee County.
Data (1995) from specimens in the Florida State Collection of Arthropods and from Division of Plant Industry files represent the following Florida localities: Glen St. Mary, Baker County; Blountstown, Calhoun County; Chattahoochee, Gadsden County; Tampa and Valrico, Hillsborough County; Umatilla, Lake County; Torreya State Park, Liberty County; Bradenton, Manatee County; Plymouth, Orange County; Port Richey, Pasco County; Auburndale and Winter Haven, Polk County; Apopka and Longwood, Seminole Country; Hastings and St. Augustine, St. Johns County; Palm Valley, Flagler County.

\section{Identification}

At a length of 10 to $16 \mathrm{~mm}, M$. coryli is one of the largest leaf beetles in the United States. Its size and orange and metallic blue coloration make the adults easily recognized. The large (up to $20 \mathrm{~mm}$ in length) orange larvae are also conspicuous and easily recognized. The other coleopterous pest of elms, the elm leaf beetle (Pyrrhalta luteola Muller), is much smaller (6 to $7 \mathrm{~mm}$ ) and has longitudinal stripes on the elytra instead of transverse maculae. It also occurs

1. This document is EENY-180 (originally published as DPI Entomology Circular 370), one of the Featured Creatures series of the Entomology and Nematology Department, Cooperative Extension Service, Institute of Food and Agricultural Sciences, University of Florida. Published: November 2000. This document is also available on Featured Creatures Website at http://creatures.ifas.ufl.edu. Please visit the EDIS Website at http://edis.ifas.ufl.edu Additional information on these organisms, including many color photographs, is available at the Entomology and Nematology Department website at http://entnemdept.ifas.ufl.edu/.

2. Michael C. Thomas, Florida Department of Agriculture and Consumer Services, Division of Plant Industry, Gainesville, FL.

The Institute of Food and Agricultural Sciences (IFAS) is an Equal Employment Opportunity - Affirmative Action Employer authorized to provide research, educational information and other services only to individuals and institutions that function without regard to race, creed, color, religion, age, disability, sex, sexual orientation, marital status, national origin, political opinions or affiliations. For information on obtaining other extension publications, contact your county Cooperative Extension Service office. Florida Cooperative Extension Service / Institute of Food and Agricultural Sciences / University of Florida / Larry R. Arrington, Interim Dean 
in Florida, but it does not seem to be a serious pest in the state.

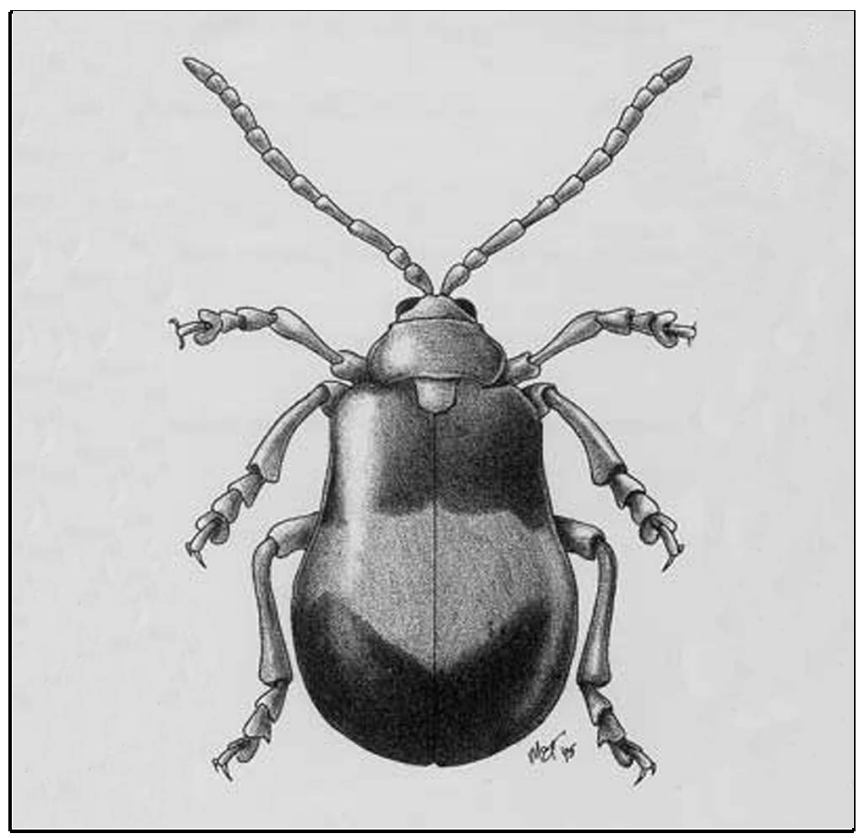

Figure 1. Adult larger elm leaf beetle, Monocesta coryli (Say). Credits: Division of Plant Industry

\section{Biology}

Kelsheimer (1945) reviewed the biology of this species in Florida, and the following information is drawn from his account of a population at Bradenton. There is only one generation per year. Eggs are laid in the spring in "hard yellow crusty" masses of 24 to 58 eggs on the undersides of elm leaves. They hatch in about two weeks.

The newly eclosed larvae are about $3 \mathrm{~mm}$ long and greenish-yellow. They are gregarious for three to four days and feed on leaf surfaces before dispersing. The mature larvae crawl down the tree and undergo a wandering phase for a few days before entering the ground, where they remain until pupation the following late winter or early spring. Pupation lasts about a month and adults begin emerging in April. Adults are active from April until early August, with most records from June to July. Both adults and larvae exude an orange, presumably defensive, fluid when disturbed.

\section{Hosts}

Monocesta coryli has been recorded as feeding on elms (Ulmus spp.) and hazel (Corylus spp.), as well as hawthorn (Crataegus sp.), red birch (Betula nigra L.), and pecan (Carya illinoensis (Wang.) K. Koch.) (Anderson and Papp 1961). Florida host records from specimens in the FSCA and from DPI files include: Nolina recurvata (Lem.) Hemsl., Cephalanthus occidentalis L., Citrus $x$ paradisi Macfad., Citrus sinensis (L.) Osbeck, Citrus sp., Cycas revoluta Thunb., Impatiens sp., Passiflora incarnata L., Passiflora sp., Rhododendron sp., Ulmus americana L. var. floridana (Chapm.) Little, Ulmus sp. Undoubtedly, the records from plant genera other than Ulmus represent resting or incidental records.

Damage sometimes can be severe. A DPI record from Bradenton in 1957 estimated 1,000 beetles per tree and noted: "Not since 1944 have we seen elm trees so 'burned'. Looks like Jap[anese] beetle damage at a distance. The leaves are brown and many have dropped." Kelsheimer (1957) also estimated 1,000 beetles per tree in that infestation, and Madden (1940) reported larvae "completely skeletonized" elms at Quincy.

\section{Management}

Apparently, parasites normally keep populations of M. coryli at non-economic levels. Kelsheimer (1945) noted a dramatic decrease in population level the year after an outbreak, with a very high rate of parasitism. The necessity of the larvae to crawl down the tree to pupate in the soil suggests a vulnerable stage in the life cycle that could be exploited in a control strategy.

For more information see: Insect Management Guide for Woody Ornamentals (http://edis.ifas.ufl.edu/IG012).

\section{Selected References}

Anderson D, Papp CS. 1961. The larger elm leaf beetle, Monocesta coryli (Say). Proceedings of the Entomological Society of Washington 63: 203-207.

Blatchley WS. 1924. The Chrysomelidae of Florida. The Florida Entomologist 7: 33-39, 49-57; 8: 1-7, 17-23, 39-46. 
Clark SM. 1986. Occurrence of Monocesta coryli (Say) in Ohio (Coleoptera: Chrysomelidae). Ohio Journal of Science 86: 213.

Kelsheimer EG. 1945. Notes on the great elm leaf beetle. The Florida Entomologist 28: 25-27.

Kelsheimer EG. 1957. Larger elm leaf beetle (Monocesta coryli). Cooperative Economic Insect Report, Plant Pest Control Division, Agricultural Research Service, U.S. Department of Agriculture 7: 650 .

Madden AH. 1940. Larger elm leaf beetle (Monocesta coryli Say). Insect Pest Survey Bulletin, Bureau of Entomology and Plant Quarantine, U.S. Department of Agriculture 20: 408.

Wilcox JA. 1965. A synopsis of the North American Galerucinae (Coleoptera: Chrysomelidae). New York State Museum and Science Service Bulletin No. 400. 226 p. 